\title{
Cutaneous Burn Wound caused by Liquid Ammonia: Case Report
}

\author{
Sivı Amonyak Uygulanmasının Neden Olduğu Cilt Yanığı: \\ Olgu Sunumu
}

\section{Medeni Volkan Kıyak ${ }^{1}$, Mustafa Burak Sayhan², Cemil Kavalcı ${ }^{3}$, Can Kopal ${ }^{4}$, Mehmet Ünaldı ${ }^{5}$}

${ }^{1}$ Edirne Devlet Hastanesi, Plastik Cerrahi Kliniği, Edirne, Türkiye

${ }^{2}$ Edirne Devlet Hastanesi, Acil Tıp Kliniği, Edirne, Türkiye

${ }^{3}$ Trakya Üniversitesi Tip Fakültesi Acil Tip Kliniği,Edirne, Türkiye

${ }^{4}$ Diyarbakır Asker Hastanesi, Plastik Cerrahi Kliniği, Diyarbakır, Türkiye

${ }^{5}$ Kartal Eğitim ve Araştırma Hastanesi, Acil Tıp Kliniği, İstanbul, Türkiye

\section{ABSTRACT}

Ammonia related injuries are rarely seen but they are associated with high morbidity and mortality. Liquid ammonia burns the skin through a freezing mechanism, a thermal mechanism, and an alkali burn as well. The burn associated with liquid ammonia is multifactorial. In this case report we aimed to point out the pathophysiology and treatment of cutaneous burn wound caused by liquid ammonia.

Key words: Liquid ammonia, burn, injury

\section{ÖZET}

Amonyak ilişkili yaralanmalar nadirdir fakat yüksek mortalite ve morbitideye neden olurlar. Sivı amonyak nedenli deri yanıklarının mekanizması multifaktöriyeldir ve alkali yanıkların mekanizmasına benzerdir. $\mathrm{Bu}$ olgu sunumunda sıvı amonyak uygulanması sonucu gelişen yanık lezyonunun patofizyolojisi ve tedavisini ortaya koymayı amaçladık.

Anahtar kelimeler: Sıvı amonyak, yanık, yaralanma 


\section{BACKGROUND}

Ammonia has a potential to cause grave damage due to its toxic, alkaline chemical nature. In addition, it may cause a frostbite injury due to its cooling effect ${ }^{(1)}$. Ammonia can be highly corrosive when mixed with water ${ }^{(2)}$. Pressurized liquids and gases exert an additional cold thermal injury and this may complicate the clinical picture ${ }^{(3)}$. The injuries associated with ammonia burns are specific to the effects of ammonium hydroxide. Severity of symptoms and tissue damage produced is directly related to the concentration of hydroxyl ions ${ }^{(4)}$. In this case report we aimed to point out the pathophysiology and treatment of cutaneous burn wound caused by liquid ammonia.

\section{CASE REPORT}

An 8-year-old female, in an attempt to eliminate pain and edema due to a bee sting, placed gauze pads with liquid ammonia to the left side of his face (Figure 1). Physical examination of the conscious patient revealed a body temperature of $36.6^{\circ} \mathrm{C}$, arterial blood pressure of $120 / 85 \mathrm{~mm}$ $\mathrm{Hg}$, pulse rate of approximately 74 beats/min, and respiratory rate of 20 breaths $/ \mathrm{min}$. She had a Glasgow Coma Scale Score of $15 / 15$. There was no hyperleukocytosis and there were no other abnormalities apparent upon clinical examination. Chest radiography was normal. She had not done any exchange of the pads or dressing of the wound during the next six days. On sixth day, profound second degree burns developed on the area under lesion, and he presented to our emergency department. Firstly her cutaneous burns area was thoroughly irrigated with water. The burn wound was covered with $1 \%$ silver sulphadiazine cream. Antibiotic prophylaxis (30 $\mathrm{mg} / \mathrm{kg} /$ gün Ampicillin-sulbactam) was administered to the patient for a seven days period. The wound was not debrided. Her cutaneous burns area was dressed daily with $1 \%$ silver sulphadiazine cream. The lesion recovered without scar.

\section{DISCUSSION}

Ammonia is a colorless gas with a strong, pungent and irritating odor ${ }^{(3)}$. Ammonia injury is an uncommon injury, but it is associated with high morbidity and mortality ${ }^{(5)}$. Solutions of ammonia are used as household cleaners, particularly for glass. These solutions are irritating to the eyes and mucous membranes (respiratory and digestive tracts), and to a lesser extent the skin ${ }^{(6)}$

When the vapor from the desiccation of the liquid ammonia is inhaled, it can cause significant pulmonary injury, including upper airway and pulmonary edema, desquamation of bronchial epithelium, and bronchopneumonia ${ }^{(5)}$.

The most common mechanism by which ammonia gas causes damage occurs when anhydrous ammonia (liquid or gas) reacts with tissue water to form the strongly alkaline solution, ammonium hydroxide ${ }^{(6)}$.

Liquid ammonia burns the skin through a freezing mechanism, a thermal mechanism, and an alkali burn as well. The burn associated with liquid ammonia is multifactorial.
The freezing of tissue causes extracellular crystal formation and direct cellular damage ${ }^{(7)}$. Ammonia dissolves in water to form ammonium hydroxide which dissociates to form hydroxyl ions, the concentration of which will determine the extent of tissue damage ${ }^{(6)}$. Skin necrosis occurs by the formation of ammonium hydroxide, causing a liquefaction necrosis ${ }^{(8)}$. Our patient did not use pressurized liquids and gases but she used household ammonia which is a solution of $\mathrm{NH}_{3}$ in water.

George et al. ${ }^{(3)}$ reported an adult male patient who had liquid ammonia injury due to accidental exposure and suffered cold thermal and chemical injury with some systemic complications and had a fatal outcome. Our patient applied to her face liquid ammonia to relieve the pain due to insect bite. The degree of tissue injury, however, is proportional to the duration and concentration of exposure ${ }^{(9)}$. She did not do any exchange of the pads during the following six days. In this patient severe cutaneous burns happened due to the fact that exposure time was prolonged and no washing.

Figure 1: Reddish edema with second degree burn at the left side of his face is seen.

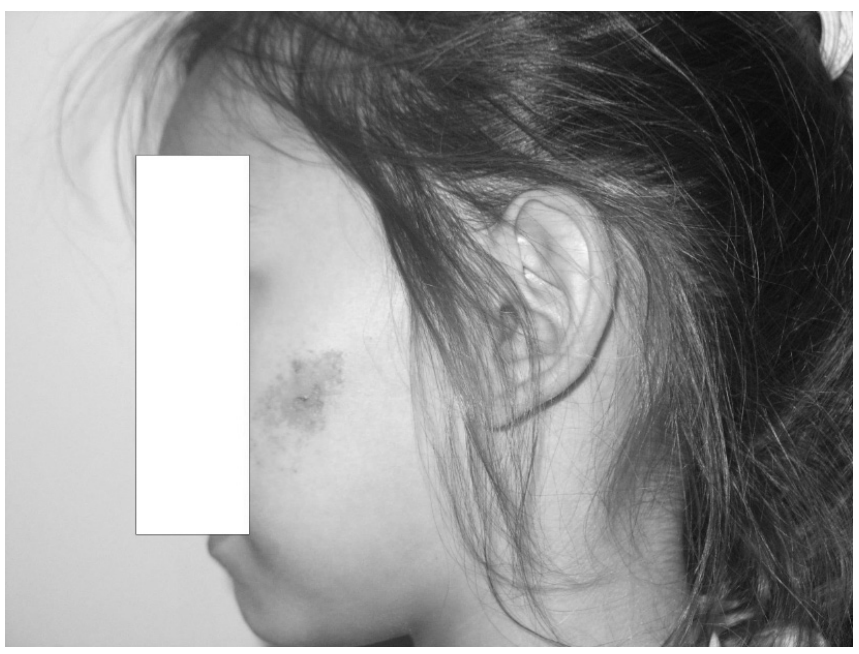

\section{CONCLUSION}

Patients exposed to pressurized liquids or gases present unique diagnostic and treatment challenges to the Emergency physicians. Aggressive initial management, significantly can reduce morbidity of ammonia. 


\section{REFERENCES}

1. Sotiropoulos G, Kilaghbian T, Dougherty W, Henderson SO. Cold injury from pressurised liquid ammonia: a report of two cases. J Emerg Med. 1998;16:409-12.

2. Hall SK. Toxic responses of the lung. In: Hall SK, Chakraborty J, Ruch RJ, editors. Chemical exposure and toxic responses. Boca Raton: Lewis Publishers, 1997. p. 82-3.

3. George A, Bang RL, Lari A, Gang RK, Kanjoor JR. Liquid ammonia injury. Burns 2000;26:409-13.

4. Millea TP, Kukan JO, Smoot III EC. Anhydrous ammonia injuries. J Burn Care Rehab. 1989;10: 448-53.
5. Arwood R, Hammond J, Ward G: Ammonia inhalation. J Trauma. 1985;25:444-7.

6. Rom WN. In: Enviornment and occupational medicine, 2nd ed. Boston: Little Brown \& Co, 1992. p. 529-30.

7. Trott A: Mechanisms of soft tissue trauma. Ann Emerg Med. 1988;17:1279-83.

8. O'Kane GJ: Inhalation of ammonia vapor: a report on the management of eight patients during the acute stages. Anaesthesia 1983;38:1208-13.

9. Sotiropoulos G, Kilaghbian T, Dougherty W, Henderson SO. Cold injury from pressurized liquid ammonia: a report of two cases. J Emerg Med. May-Jun. 1998;16:409-12. 